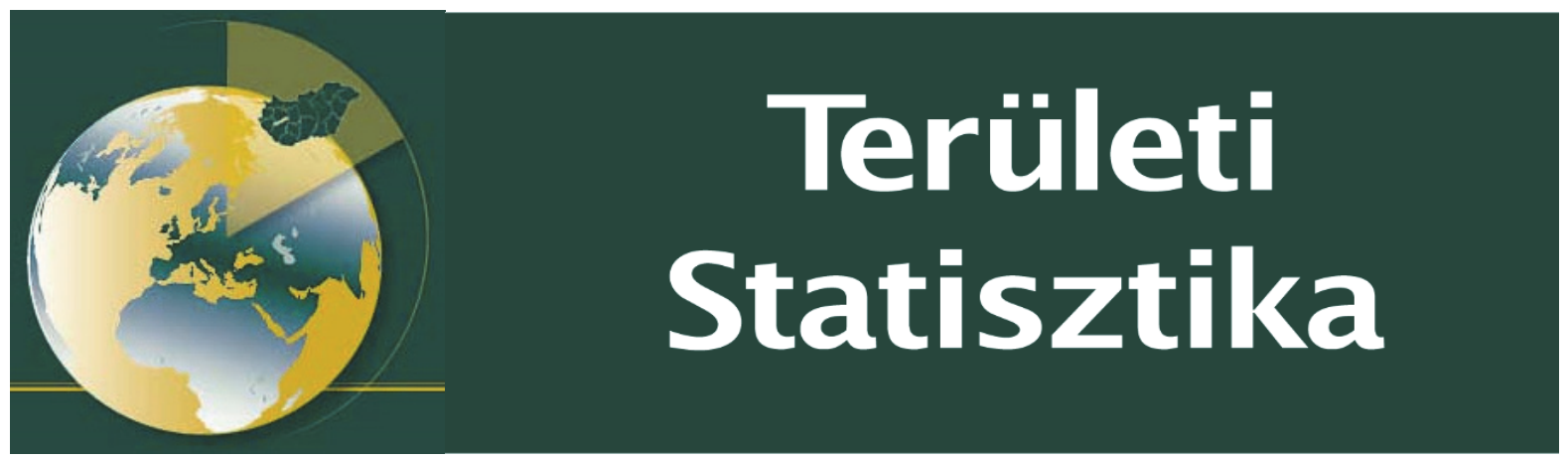

Közzététel: 2020. július 24 .

A tanulmány címe:

Felvillanyozva: az elektromos autók töltőhálózatának terjedése Magyarországon

Szerző:

Gerse József

https://doi.org/10.15196/TS600403

Az alábbi feltételek érvényesek minden, a Központi Statisztikai Hivatal (a továbbiakban: KSH) Területi Statisztika c. folyóiratában (a továbbiakban: Folyóirat) megjelenó tanulmányra. Felhasználó a tanulmány, vagy annak részei felhasználásával egyidejüleg tudomásul veszi a jelen dokumentumban foglalt felhasználási feltételeket, és azokat magára nézve kötelezönek fogadja el. Tudomásul veszi, hogy a jelen feltételek megszegéséböl eredö valamennyi kárért felelösséggel tartozik.

1) A jogszabályi tartalom kivételével a tanulmányok a szerzői jogról szóló 1999. évi LXXVI. törvény (Szjt.) szerint szerzői műnek minősülnek. A szerzői jog jogosultja a KSH.

2) A KSH földrajzi és időbeli korlátozás nélküli, nem kizárólagos, nem átadható, térítésmentes felhasználási jogot biztosít a Felhasználó részére a tanulmány vonatkozásában.

3) A felhasználási jog keretében a Felhasználó jogosult a tanulmány:

a) oktatási és kutatási célú felhasználására (nyilvánosságra hozatalára és továbbítására a

4. pontban foglalt kivétellel) a Folyóirat és a szerző(k) feltüntetésével;

b) tartalmáról összefoglaló készítésére az írott és az elektronikus médiában a Folyóirat

és a szerző(k) feltüntetésével;

c) részletének idézésére - az átvevő mú jellege és célja által indokolt terjedelemben és az eredetihez híven - a forrás, valamint az ott megjelölt szerző(k) megnevezésével.

4) A Felhasználó nem jogosult a tanulmány továbbértékesítésére, haszonszerzési célú felhasználására. Ez a korlátozás nem érinti a tanulmány felhasználásával elóállított, de az Szjt. szerint önálló szerzői műnek minősülő mú ilyen célú felhasználását.

5) A tanulmány átdolgozása, újra publikálása tilos.

6) A 3. a)-c.) pontban foglaltak alapján a Folyóiratot és a szerző(ke)t az alábbiak szerint kell feltüntetni:

„Forrás: Területi Statisztika c. folyóirat 60. évfolyam 4. számában megjelent, Gerse József által irt, Felvillanyozva: az elektromos autók töltöbálózatának terjedése Magyarországon c. tanulmány"

7) A Folyóiratban megjelenő tanulmányok kutatói véleményeket tükröznek, amelyek nem esnek szükségképpen egybe a KSH, vagy a szerzők által képviselt intézmények hivatalos álláspontjával. 


\section{Felvillanyozva: az elektromos autók töltöhálózatának terjedése Magyarországon}

\section{Electrifying system: how public electric car chargers spread in Hungary}

\author{
Gerse, József \\ Központi Statisztikai Hivatal \\ E-mail: jozsef.gerse@ksh.hu
}

Kulcsszavak: közlekedésföldrajz, e-mobilitás, elektromos járművek, elektromos töltőállomás

Keywords: transport geography, e-mobility,

electric vehicles,

electric charging station
A tanulmány az elektromos autókat energiával ellátó nyilvános gyorstöltők 2010 és 2019 közötti magyarországi területi terjedését mutatja be. A töltőhálózatot elsősorban aszerint vizsgálja a szerző, hogy azok mely településeken érhetők el; a helyszínek és a csatlakozási pontok számát, a töltők múszaki jellemzőit melyek arra vannak hatással, hogy milyen autótípusok használhatják ténylegesen az adott helyszínt - másodsorban jeleníti meg. Az országos hálózatban a 2010-es évek elsố felében gyakoriak voltak a lefedetlen foltok, az évtized végére azonban jelentősen megnőtt a lefedett területek nagysága, ennek fó hajtóerőit is sorra veszi a tanulmány. Adatforrásként főként a villanyautós közösség egyik hazai internetes oldala, valamint töltópontokat mutató térképes alkalmazások szolgáltak.

This study shows how the network of public electric car (fast) chargers developed in Hungary during the previous decade. The research focuses on the availability of these on settlement level, the exact number of charging locations and points; the quality and technical details of the chargers - which determine whether a certain car type can use it or not were secondary considerations. There were many uncovered spots in the country in the early 2010s, but the network significantly developed by the end of the decade. The main reasons behind the growth are also discussed. The main data sources were one major Hungarian electric car website and certain echarger mapping applications.

Beküldve: 2020. március 19.

Elfogadva: 2020. április 6.

Területi Statisztika, 2020, 60(4): 461-476; DOI: 10.15196/TS600403 


\section{Egyre többen vásárolnak elektromos autót}

Az elektromos járművek világszerte divatba jöttek az elmúlt években (Orbulov-Lógó 2020), mivel a fosszilis üzemanyaggal múködő társaikhoz képest potenciálisan tisztább és fenntartási szempontból olcsóbb alternatívát jelentenek. (Jelen tanulmánynak nem célja környezeti vonatkozású értékelésük.) Vásárlásukat és használatukat különböző intézkedésekkel igyekeztek fellendíteni, sőt, lassan kikényszeríteni, ugyanis több ország bejelentette, hogy egy-két évtizeden belül betiltják a klasszikus benzin- és dízelüzemú autókat.

A lakosság hozzáállásában is megjelenik a környezetkímélő közlekedés igénye. Baranyai és Varjú (2017) kutatásában a válaszadók egyik leggyakrabban a „közlekedés” és az „energiaforrás” témakörébe tartozó megoldásokat említették azzal kapcsolatban, hogy milyen területeken várnak állami beavatkozást a klímaváltozás lassítására.

Magyarországon 2016 és 2018 között állami támogatásra lehetett pályázni új elektromos autó beszerzésére, melyekkel a nagyobb városokban általában ingyenes a parkolás, a hajtóanyagot biztosító áramból pedig 2018-2019-ig ingyen lehetett „feltankolni" a közterületi töltőpontok többségén. Utóbbi kedvezmény megszüntetése már önmagában a villanyautók növekvő piaci szerepére enged következtetni (Vokony et al. 2020), ugyanis a KSH adatai ${ }^{1}$ szerint 2015 végéig az 500-at sem érte el a hazánkban nyilvántartott, kizárólag elektromos meghajtású személygépkocsik száma, de állományuk 2019-ig minden évben nagyjából megduplázódott. 2019 végén mintegy 6600 darabot tartottak nyilván belőlük (1. ábra). Ezen felül a kizárólag elektromos meghajtású teher- és különleges célú gépjármúvek, autóbuszok száma meghaladta az 500-at, a motorkerékpároké pedig a 200-at.

1. ábra

\section{Az elektromos személygépkocsik számának alakulása Magyarországon}

Changes in the number of electric passenger cars in Hungary

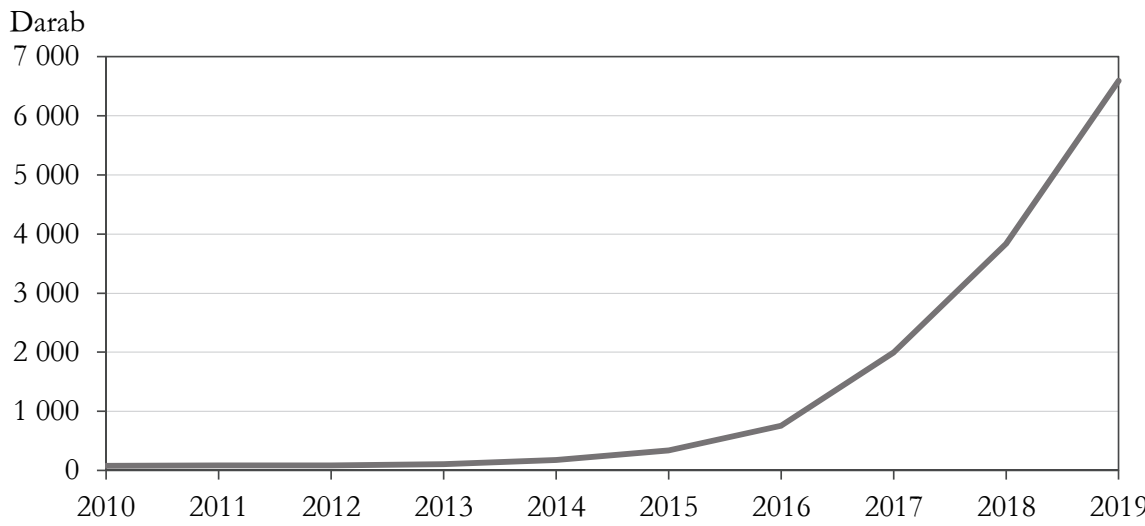

Forrás: A KSH adatai alapján saját szerkesztés.

1 A Közigazgatási és Elektronikus Közszolgáltatások Központi Hivatalától és a Belügyminisztériumtól átvett adatok.

Területi Statisztika, 2020, 60(4): 461-476; DOI: 10.15196/TS600403 
A külső hálózatról tölthetô autók széles körű elterjedéséhez azonban szükséges a megfelelő töltőinfrastruktúra is (Csiszár et al. 2017), melynek hiányában egyrészt nem lehet hosszabb utakat megtenni. A 2010-es évek első felében az elektromosjármú-kínálat nagy részének 150-200 kilométer alatti volt a hatótávja², ezt a tartományt az évtized végére sikerült a legtöbb gyártónak túllépni, több modellnél akár meg is többszörözni.

Másrészt nem mindegy, hogyan oldható meg a töltés: hagyományos dugaljzatról vagy annál kicsit erősebb, különböző változatokban kapható speciális töltőeszközről (wallbox), ugyanis az közel fél napba is beletelhet. Ez nem gond olyankor, amikor az autó amúgy nincs használatban (például éjszaka vagy a munkaidő alatt), viszont az időigényes folyamat miatt egy járművezetőnek nem praktikus, ha csak ilyen berendezésnél tud megállni egy hosszabb út során, ezek jellemzően „mentőövként” hasznosak. A rövidebb távú vezetéshez, például a napi munkába járáshoz általában elegendők az otthoni környezetben elérhető töltési lehetőségek, még a lakóhelyhez képest eltérő településre közlekedés esetén is. Kiss-Szalkai (2018) a népszámlálás adataiból arra következtetett, hogy Magyarországon 2011-ben a más, konkrét belföldi településre ingázó - nem feltétlenül a csak autóval közlekedő - foglalkoztatottak több mint háromnegyede, közel 900 ezer fő (közúton) 30 kilométernél rövidebb távolságra lakott a munkahelyétől, ami oda-vissza a legtöbb elektromos autóval egy feltöltéssel gond nélkül megtehetô távolság.

Az elektromos közlekedés nyilvános feltételeit gyors- és villámtöltőkkel javítják, hogy a „tankolás” minél rövidebb ideig tartson, illetve adott idő alatt minél jobban feltöltődjön az akkumulátor. Legalább $22 \mathrm{~kW}$ teljesítménnyel (gyorstöltőn) az autó - típusától függően - néhány óra alatt teljesen feltölthető, 43 kW-tól (villámtöltőn) mindehhez egy óra sem szükséges (Csiszár et al. 2017). Sőt, már kifejlesztettek ennél is nagyobb $(>75 \mathrm{~kW})$ teljesítményú, ún. ultragyors villámtöltőket is.

Fontos megemlíteni, hogy ugyanazon hálózatok kapacitását nem minden autó képes maximálisan kihasználni, egy akkumulátor teljes feltöltésének ideje több elektromos tulajdonságtól függ (például az áramerôsségtől és a fázisok számától). Az említett töltési teljesítményre utaló jelzők, megnevezések és határértékek ugyanakkor nem hivatalosak, a villamos hálózati tulajdonságok figyelembevételével néhol például gyorstöltőként hivatkoznak már a $11 \mathrm{~kW}$-ra, villámtöltoóként a $22 \mathrm{~kW}$-ra is.

2 A hatótávot befolyásolja a vezetési stílus és az akkumulátor állapota, de a klíma vagy a fũtés bekapcsolása és az időjárás is. Mérését bonyolítja továbbá, hogy a különböző piacokon különböző tesztek eredményeit tekintik mércének, ezért a gyári adatoknál különböző értékek szerepelnek. Ezek ráadásul sokszor a maximálisan megtehető úthosszra vonatkoznak, de hétköznapi használattal ehhez képest jellemzően több tíz kilométerrel rövidebb távolsággal érdemes számolni, főleg autópályán, mivel az elektromos járműveknek nagy sebességnél, autópályán arányaiban jobban megnő a fogyasztása, mint a benzineseknek vagy dízeleseknek. Az akkumulátor kapacitása is csökken idővel. A szerteágazó paraméterek miatt az elemzésben két általános hatótávot ragadtam meg: minimumnak a legkedvezôtlenebb körülmények esetén is kompromisszumok nélkül többnyire megtehető 50 kilométert, „kicentizve” pedig 100 kilométeres maximumot választottam.

Területi Statisztika, 2020, 60(4): 461-476; DOI: 10.15196/TS600403 
Lényeges, hogy nem minden töltőpont egyforma értékű a felhasználók számára, mert a gyártók vetélkedésével az autókon ötféle, ehhez igazodva a gyors- és a villámtöltőkön négyféle csatlakozó terjedt el Európában³. Anélkül, hogy túlságosan elmélyednénk a műszaki részletekben, a háttérben az egyen- és váltóáram-ellátási, valamint -fogadási képesség áll. Ebből adódóan egyáltalán nem mindegy, hogy egy töltőállomás mennyire felszerelt az egyes típusokból, az összekötés ugyanis még átalakító eszközök segítségével is csak korlátozottan oldható meg (1. táblázat).

1. táblázat

\section{A töltőberendezések és az elektromos autók csatlakozófajtáinak kompatibilitása} (az átalakító eszközök meglétének figyelembevételével)

Compatibility of chargers and car connector types (including adapter options)

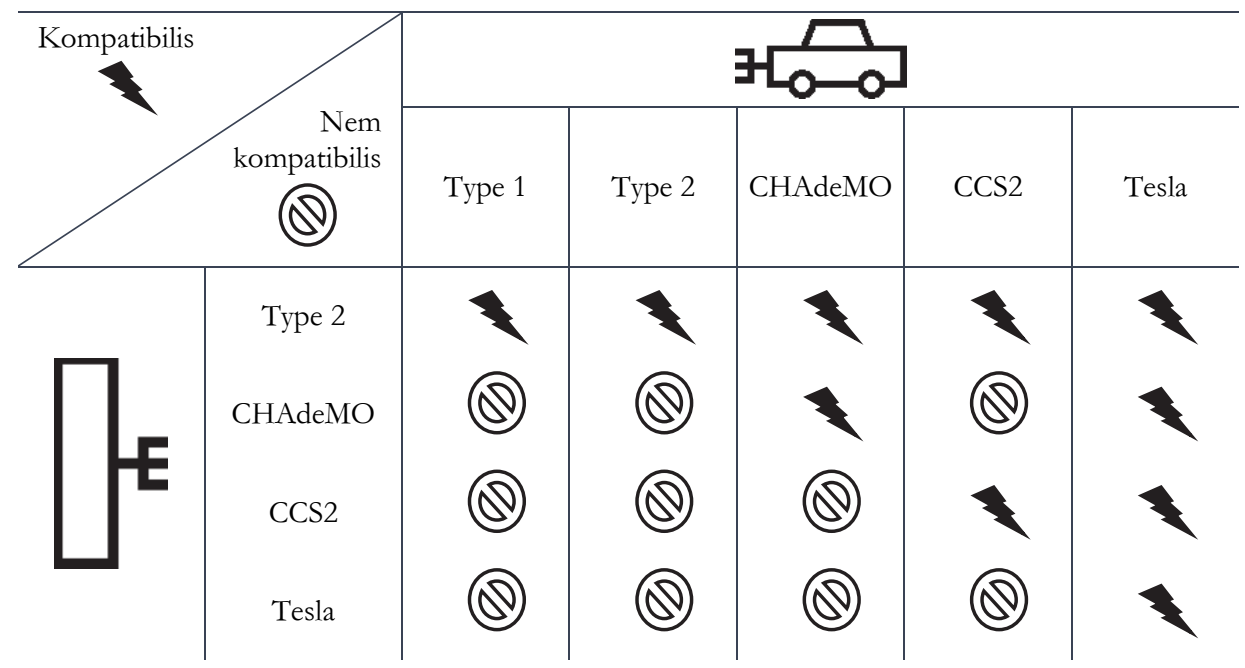

Forrásoldalon a Type 2 csatlakozó univerzális, bármely másikhoz illeszthető. ${ }^{4}$ A CCS2 és CHAdeMO szabványról viszont nem fogad áramot egy csak Type 2 csatlakozós modell, mert e két rendszer között sincs átjárás.

Speciális esetnek számít a vizsgált téma talán legismertebb forradalmára, a Tesla, ugyanis a jármúveihez készített és telepített töltők nem kompatibilisek más gyártók autóival, ́́gy azok tulajdonosai nem tudják igénybe venni őket. Fordítva azonban múködik az ellátás, a „teslások” külön kábellel Type 2, CHAdeMO, illetve 2019 óta CCS2 konnektort is használhatnak. Ebből kifolyólag a csak Tesla-csatlakozót bizto-

\footnotetext{
${ }^{3}$ Egy járműre több aljzatot is rakhatnak, a legjellemzőbb a Type 2-CCS2 és a Type 1-CHAdeMO párosítás. Néhány különleges modellben másfajta csatlakozót használnak. Type 1 típusú töltőpont nem jellemző a kontinensen, ilyen csatlakozó pedig önmagában csak régebbi kocsikban fordul elő. Európán kívül létezik még a CCS1 szabvány, valamint Franciaországban és Olaszországban találhatók Type 3 típusú konnektorok, melyek gyártása a 2010-es évek elején megszűnt (Spöttle et al. 2018).

${ }^{4}$ Kivéve, amennyiben a töltôt fix kábellel telepítették, mert ez csak Type 2 csatlakozós járművel kompatibilis. Ilyen állomásból néhány található hazánkban.
} 
sító töltőhelyeket figyelmen kívül hagytam a vizsgálat során, lévén e márka autóiból alig több mint négyszáz darabot tartottak nyilván hazánkban 2019 végén, ami kis szelete az elektromosjármú-állománynak. A magyarországi Tesla-tápegységeket többnyire autópályák és nagyvárosok szomszédságában, valamint néhány dunántúli vendéglátóegységnél helyezték üzembe.

Számos helyen mindhárom gyakori konnektorfajtát telepítették, de többségben vannak azok a helyek, ahol nincs így. Az univerzális Type 2 az állomások többségén megtalálható volt 2019 végén, de bizonyos pontokon csak CCS2 és CHAdeMO múködött. Emellett elvétve előfordulnak olyan parkolók, ahol kizárólag CHAdeMO várja a közlekedôket (jellemzően az egyik autómárka által telepített helyszíneken). Érdekesség, hogy utóbbi elnevezése egy japán kifejezésből származik, és egy teázásnyi időre utal; ebből is sejthető, hogy míg ezt a szabványt a japán gyártók preferálják, addig az előbbi kettôt az európaiak. Kizárólag CCS2-en keresztül történő áramvételi lehetőség két helyen létezik, 2019 óta. Az egyes állomásoknak így különbözik a szolgáltatási körzete, ami főleg 2014 és 2017 közötti adatok vizsgálatát tette bonyolulttá, mivel ebben az idôszakban néhol csak a CHAdeMO típussal kompatibilis autót vezetôk számára volt elérhetô közelségben töltőpont. Ez azért lényeges, mert a legfrissebb jármúállomány-adatok szerint 2019 végén az elektromos személygépkocsik közel felét tölthették CHAdeMO csatlakozóról (a KSH, Belügyminisztériumtól származó adatai, valamint a https://gyorstoltok.hu/elektromos-autok-estoltocsatlakozoik oldalon található információk alapján). 2018-tól elkezdődött az ország általános lefedése Type 2 oszlopokkal, ami megszüntette a körzetekkel kapcsolatos problémát.

Az elektromos közlekedés szóhasználatában eltérő jelentése van az (1) töltőberendezés, a (2) töltőpont, a (3) töltőállomás, a (4) töltőhely fogalmának: ezeken sorrendben (1) az áramot biztosító eszközt, (2) ennek egy vagy több csatlakozóját (kimenetét), (3) azonos helyen lévő egy vagy több eszközt, (4) a töltésre kijelölt (parkoló)helyet értik (https://villanyautosok.hu/2019/10/23/toltotelepites-szabalyai-magyarorszagon-100-millios-birsag-a-tet). E tanulmány középpontjában a települési szintű elérhetôség áll, ezért ahol lehetséges, ott a felsorolt fogalmak egymás szinonimái.

\section{Több pillérre épül az adatok begyưjtése és értékelése}

A kutatás a legalább $11 \mathrm{~kW}$-os nyilvános berendezések elhelyezkedésével foglalkozik. Bár jelenleg a többségük teljesítménye legalább $22 \mathrm{~kW}$, az alacsonyabb küszöbértéket az idôbeli összehasonlítás indokolja, mivel eleinte kisebb teljesítményü töltóket telepítettek. Az ennél alacsonyabb teljesítményú nyilvános wallboxok és sima konnektorok közelében ma már többnyire amúgy is elérhető gyorstöltő.

A Magyarországon múkëdő hálózatról nem találtam hivatalos, pontos adatokat. 2016-tól kezdve az üzleti célú elektromostöltő-üzemeltetés engedélyköteles tevékeny-

Területi Statisztika, 2020, 60(4): 461-476; DOI: 10.15196/TS600403 
ség, amit a Magyar Energetikai és Közmű-szabályozási Hivatal hagy jóvá, de az ott fellelhető adatok egyrészt csak az engedélyezett (nem feltétlenül múködő) töltési helyszínekre vonatkoznak, másrészt a korábbi állapot megismerésére nem alkalmasak.

A Hazai Elektromobilitási Stratégia, Jedlik Ányos Terv 2.0 (ITM 2019) dokumentumban szerepelnek országosan összesített idősoros értékek az Európai Bizottság által finanszírozott European Alternative Fuels Observatory adataira hivatkozva, de alaposabb áttanulmányozást követően ezt az adatbázist nem tekintettem etalonnak. Nem tartalmaz ugyanis területi bontást, és a honlapján elérhető térképen a kutatásból kimaradó nem gyorstöltő pontok is megjelennek, illetve olyanok, amelyek feltehetőleg nem nyilvánosak, továbbá egyértelmúen hiányoznak róla az üzemelő töltőállomások. Az említett adatforrás egy magyar töltốpontjelző alkalmazás, amelynél léteznek átfogóbbak, naprakészebbek, a villanyautós közösségen belül elterjedtebbek: a Plugshare és az Open Charge Map. Az adatgyújtés ezekre épült (2. táblázat), kiegészítve a töltőavatásokról interneten megjelenő és könnyen hozzáférhető cikkek átböngészésével. Különösen értékes adatforrás volt az elektromos jármúvet vezetők egyik hazai oldala, a villanyautosok.hu.

2. táblázat

Az adatgyüjtésnél áttekintett források információtartalma és értékelése, 2019 Content and the evaluation of the sources reviewed during the data collection, 2019

\begin{tabular}{|c|c|c|c|c|c|}
\hline Forrás & $\begin{array}{c}\text { European } \\
\text { Alternative } \\
\text { Fuels } \\
\text { Observatory }\end{array}$ & Plugshare & $\begin{array}{c}\text { Open Charge } \\
\text { Map }\end{array}$ & $\begin{array}{l}\text { Internetes } \\
\text { cikkek töltő- } \\
\text { avatásokról }\end{array}$ & Szakirodalom \\
\hline \multicolumn{6}{|c|}{ A töltőkkel kapcsolatos információk } \\
\hline Elérhetőség & nem & igen & igen & igen & nem \\
\hline Teljesítmény & részben & igen & igen & igen & részben \\
\hline Átadás éve & igen & részben & részben & igen & nem \\
\hline Területi lista & igen & igen & igen & nem & részben \\
\hline \multicolumn{6}{|c|}{ Értékelés } \\
\hline $\begin{array}{l}\text { Teljesség a hazai } \\
\text { hálózatról }\end{array}$ & részben & igen & igen & részben & részben \\
\hline $\begin{array}{l}\text { Adatok } \\
\text { felhasználása }\end{array}$ & nem & igen & igen & igen & nem \\
\hline
\end{tabular}

A Plugshare és az Open Charge Map térképén szereplő adatok összehasonlítása szintén korlátozott, mivel megjelennek benne olyan állomások is, amelyek jelen kutatásban nem szerepelnek. A nyilvános, $11 \mathrm{~kW}$-nál kisebb teljesítményú wallbox töltôkön és konnektorokon túlmenően figyelmen kívül hagytam a magánszemélyek által ingyenesen kínált, a csak egy meghatározott kör (például kizárólag adott szálloda vendégei vagy adott vállalat dolgozói) számára elérhető, a „szívességből” hasz-

Területi Statisztika, 2020, 60(4): 461-476; DOI: 10.15196/TS600403 
nálható, valamint a háttérinformáció nélküli töltési lehetőségeket. A vizsgálatba ugyanakkor bevontam azokat, amelyek használatáért egy töltés árához hasonló öszszeget kell kifizetni, például egy étteremben kávéfogyasztás, egy mélygarázsban parkolási díj, egy üzletben kis értékú vásárlás formájában. Mindebben a Plugshare és az Open Charge Map felületére érkezett visszajelzések nyújtottak segítséget. Utóbbi alkalmazások ugyanakkor nem tekinthetôk teljesen megbízható forrásoknak, mivel néhol „korlátozott” elérésűként tüntetnek fel olyan (jellemzően vendéglátó-) egységeket, ahová valójában be lehet hajtani akkumulátortöltési céllal, míg néhány helyszín mégsem tartozik közéjük.

Némelyik töltóállomás értékelése abból a szempontból bizonyult problémásnak, hogy nem használható egész nap. Ezeket végül is a vizsgálati körbe soroltam, mivel „nyitvatartási idejük” így is viszonylag hosszú, és - Boldogkőváralja kivételével egyik helyszín sincs a periférián (Tagai et al. 2018) vagy elszigetelt pozícióban a töltőhálózatban.

A vizsgálatban a hálózati adatok - az előbbiek miatt - konkrét értékek helyett nagyságrend szerint szerepelnek, azonban mindez a szolgáltatás települési elérhetőségének vizsgálatát nem befolyásolja. A felderítésben célnak tekintettem a maximális pontosság elérését, ugyanakkor előfordulhat, hogy az egyes években ábrázolt hálózat nem tökéletesen fedi a valóságot.

\section{5-ig egy térségre koncentrálódott a töltöhálózat}

A nyilvános töltők első telepítési hulláma a 2010-es évek elején indult. Egyrészt egy projektben Bécs és Budapest összeköttetését kívánták biztosítani az elektromos autók számára, ennek keretében két év alatt Budapesten, Tatán, Győrben és Mosonmagyaróváron létesítettek töltốpontokat. Bár ezek az áramforrások nem közvetlenül az autópálya mentén helyezkedtek el, elsősorban mégsem a helyi közlekedést szolgálták. Másrészt Budapest közterületén 2010-től 2012-ig összesen nagyjából tízes nagyságrendben jelentek meg töltőoszlopok a villanyjármúvek számára, a fővárosi közlekedésüzemeltető, energiaszolgáltató és egyéb vállalatok beruházásában. Harmadrészt a Balatonnál és környékén telepítettek töltőket, Székesfehérváron, Siófokon, Balatonfüreden, Keszthelyen és Fonyódon. 


\section{A 2013 végén nyilvános gyorstöltővel rendelkező települések közúti körzetei}

Road-distance areas of settlements with public fast chargers at the end of 2013

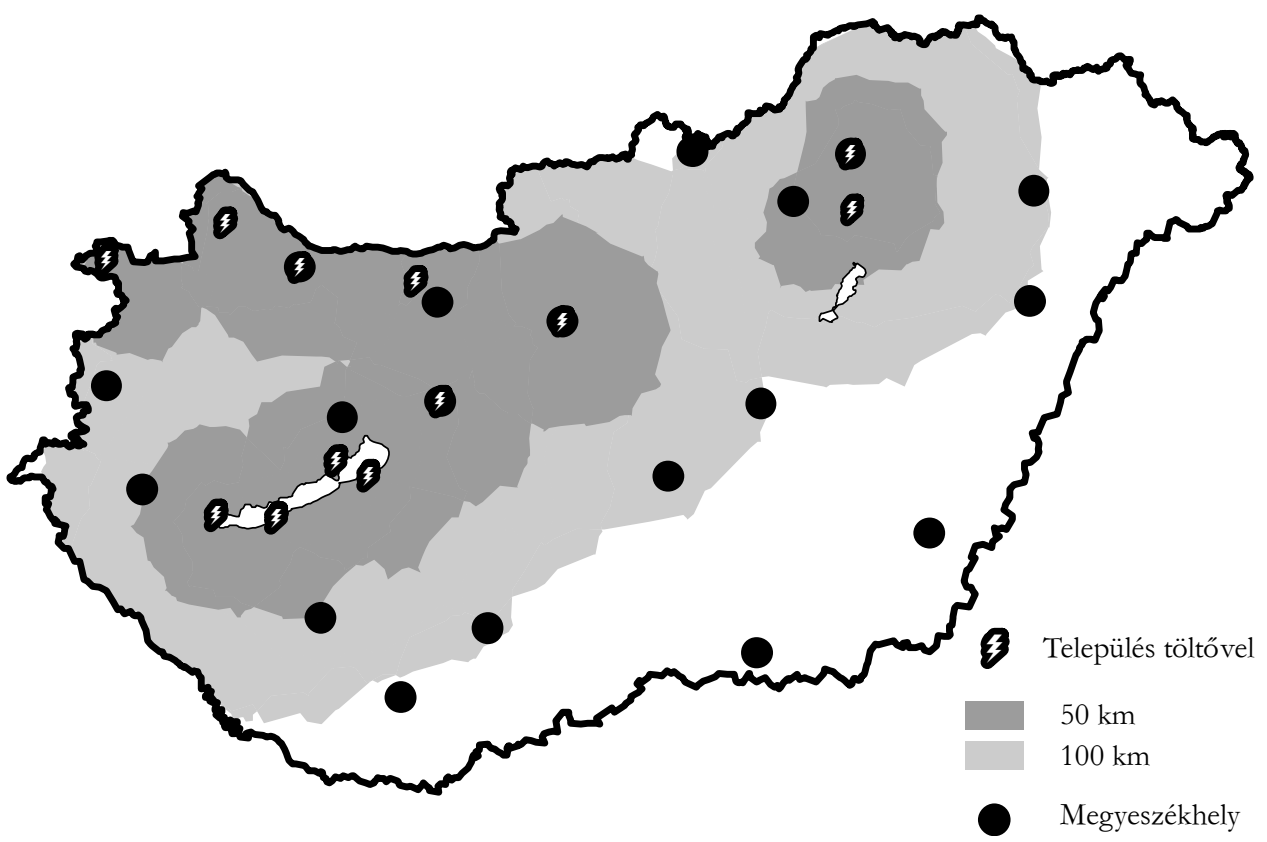

2013 végén a hálózat javarészt a Dunántúlra terjedt ki (2. ábra). A nyilvános (jellemzően Type 2) gyorstöltővel rendelkező települések úthálózaton ${ }^{5}$ mért 100 kilométeres körzetéből kiesett az Alföld jelentős része és több nagyváros is. Az 50-100 kilométeres beosztás oka az, hogy míg az 50 kilométer nagyjából akkora táv, amenynyi egy kisebb kapacitású, használt villanyautóval kedvezőtlen időjárásban nyugodtan, kompromisszummentesen megtehető anélkül, hogy - akár autópályát is használva - aggódni kellene az akkumulátor lemerülése miatt, addig „,kicentizve” nagyjából 100 kilométerre lehet eljutni. Az egyes állomásokról körülbelül a 100 kilométeres zóna széléig lehet eljutni az utóbbi esetben, de ahol két (sötét) 50 kilométeres zóna nem ér össze, az arra utal, hogy két távoli állomás között nincs töltési lehetőség.

2013-ban elektromos járművel Budapestről nem lehetett garantáltan eljutni Miskolcra, Pécsre vagy Szegedre, értelemszerūen fordítva sem. Debrecenből otthon

${ }^{5}$ A körzetek lehatárolása minden esetben a forrásként rendelkezésre álló 2010-es, csak a magyarországi közúthálózatra épült. Mivel az elérhetőség vizsgálatának alapja nem az idő, hanem a távolság volt, a szerző szerint az évtized során átadott új gyorsforgalmi szakaszok hiánya nem befolyásolja az eredményeket, ahogy az sem, hogy a töltőállomások tényleges pozíciója és a vizsgálat alapjául szolgáló települések geometriai középpontja között néhány kilométernyi eltérés lehet.

Területi Statisztika, 2020, 60(4): 461-476; DOI: 10.15196/TS600403 
Felvillanyozva: az elektromos autók töltőhálózatának terjedése Magyarországon

feltöltött akkumulátorral kivitelezhető volt a Miskolcra utazás, mert ott a visszaútra fel lehetett tölteni az autót, fordítva azonban - debreceni nyilvános töltési lehetőség híján - nem volt kivitelezhető.

A következő két év töltôhálózat-bővítésének sajátossága, hogy külön kell választani a Type 2 (+CCS2), illetve a CHAdeMO csatlakozós járművek számára elérhető helyszíneket. Az utóbbi szabványt használó egyik gyártó ugyanis 2015 végéig Debrecenbe, Szolnokra és Zalaegerszegre köztéri töltőt telepített, de ezek nem táplálják a Type 2 csatlakozós autókat. Siófokra is jutott így töltő, valamint a mogyoródi Hungaroring versenypálya bejáratához, de velük települési szinten alig bővült a hálózat 100 kilométeres elérhetősége (3. ábra).

3. ábra

\section{A 2015 végén nyilvános gyorstöltővel rendelkező települések közúti körzetei}

Road-distance areas of settlements with public fast chargers at the end of 2015

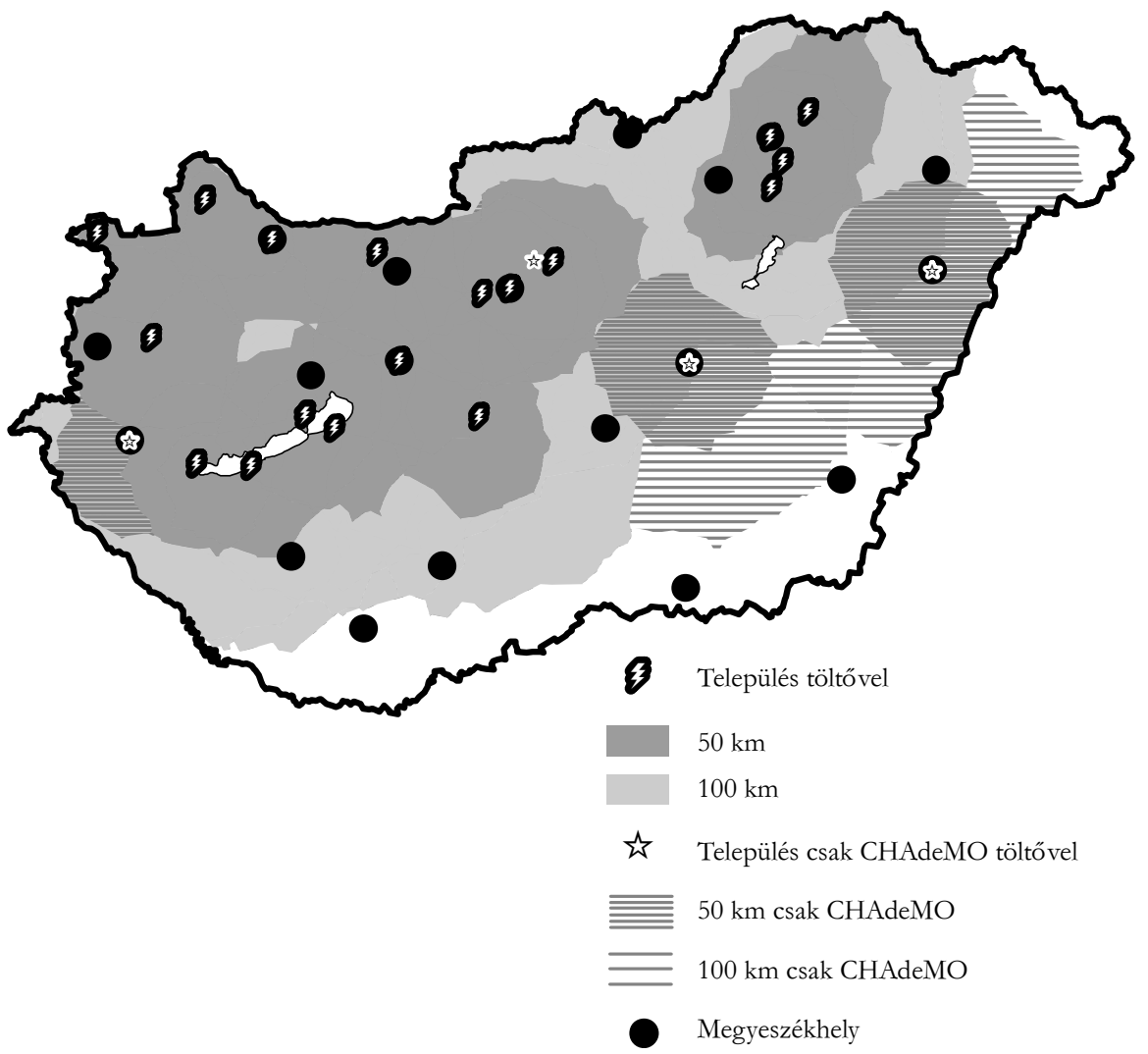

Területi Statisztika, 2020, 60(4): 461-476; DOI: 10.15196/TS600403 
A Type 2 csatlakozós villanyautók számára Dunaújvárosban és Sárváron jelentek meg új töltőpontok, ezzel a nyugati országrész és a Duna környékének lefedettsége valamelyest javult. A CHAdeMO-s hálózat ezen felül az Alföld északi részén is bővült, de onnan a nyugati országrészbe vagy a fővárosba történő kompromisszummentes utazáshoz továbbra is akadtak lefedetlen foltok.

\section{Jogszabályok tették lehetővé a lefedettség javítását 2019-ig}

2017-ig egyre több település kapcsolódott be a töltőhálózatba (4. ábra), a szolgáltatási területből hiányzó nagyobb városokban is megtörténtek az első telepítések, bevásárlóközpontokban, parkolóházakban, egyetemek, energiaszolgáltatók épületeinél. Vidéki térségekben főleg turizmushoz és autós szolgáltatásokhoz köthetően ruháztak be új töltőoszlopokba.

4. ábra

A 2017 végén nyilvános gyorstöltővel rendelkező települések közúti körzetei Road-distance areas of settlements with public quick chargers at the end of 2017

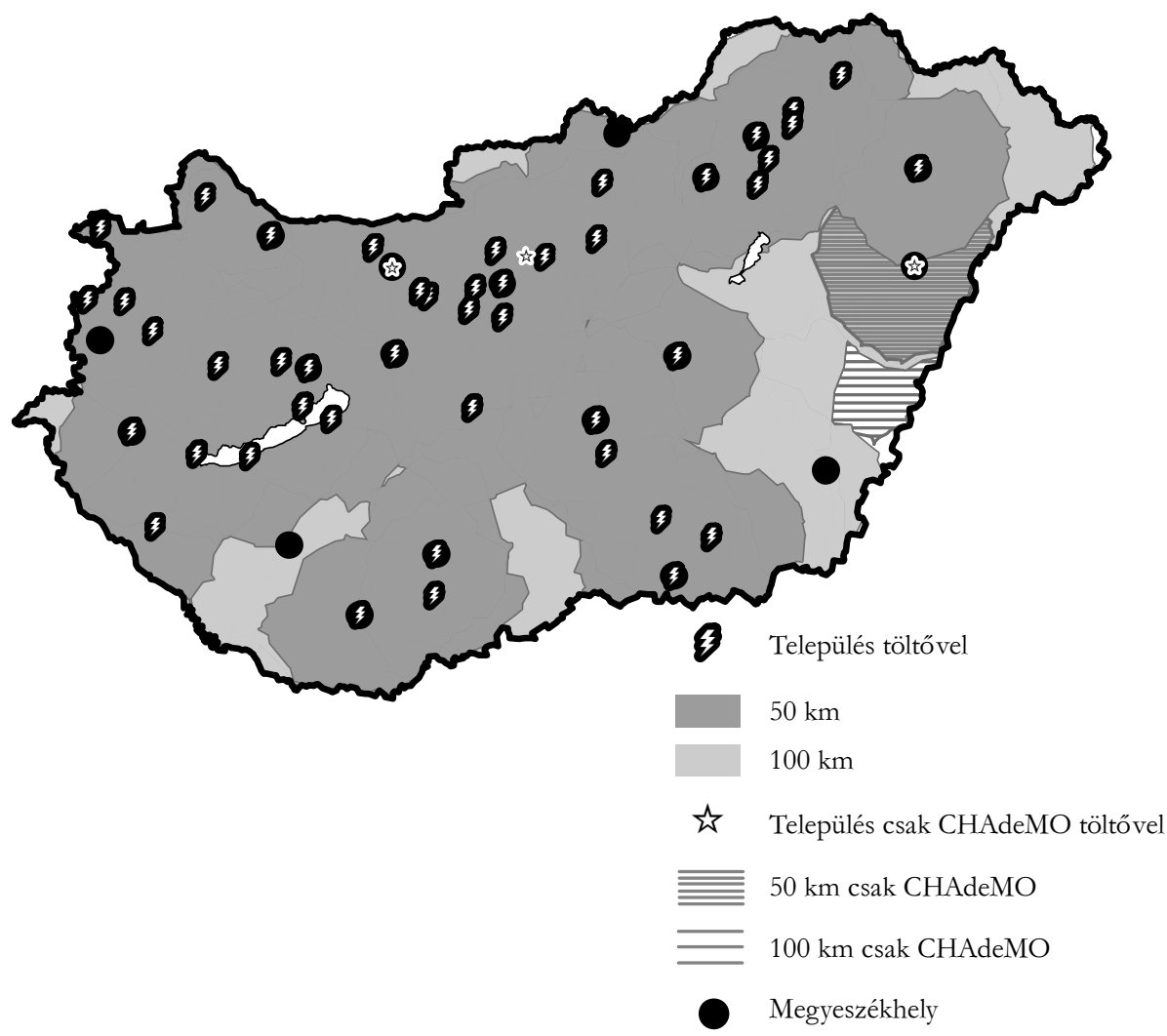

Területi Statisztika, 2020, 60(4): 461-476; DOI: 10.15196/TS600403 
A Nemzeti Közművek becslése szerint 2017-ig a hazai villanyautó-töltéseknek alig 10\%-a városi közterületen, a többi otthon vagy mélygarázsokban $(80-85 \%)$, továbbá villámtöltésekkel autópályákon és gyorsforgalmi utakon történt (5\%) (https://www.nemzetikozmuvek.hu/Hirek/2018/2018-07-12).

Az ország nyilvános gyorstöltőkkel való ellátottságának javítását alapvetően jogszabályok és egyéb intézkedések tették lehetővé 2019 végéig. Az általános lefedettségen elsôsorban a Jedlik Ányos Cselekvési Terv elfogadása lendített 2015-ben, amelyben felkérték a nemzetgazdasági minisztert arra, hogy ,gondoskodjon az elektromos járművel használatához szükséges alapvető töltőinfrastruktúra kiépítéséről, és az elektromos mobilitás terjedését szolgáló mintaprojektek indításáról az 1487/2015. (VII. 21.) Korm. határozat A Jedlik Ányos Tervhez kapcsolódó jogalkotási feladatokról (Magyar Közlöny (2015/106), 17986.) keretében 2016-ban kiírták a „Jedlik Anyos Terv" Elektromos töltöállomás alprogram helyi önkormányzatok részére pályázatot, amelyben a (2015 végén) a legalább 15 ezer fős lélekszámú települések önkormányzatai igényelhettek támogatást töltőberendezés közterületi létesítésére, „frekventált” helyen.

2017-ben a 443/2017. (XII. 27.) Korm. rendelet Az elektromobilitás hazai elterjesztésével kapcsolatos egyes állami feladatokról (Magyar Közlöny (2017/225), 35833.) nyomán megalapították az Innovációs és Technológiai Minisztérium felügyelete alá tartozó e-Mobi Elektromobilitás Nonprofit Korlátolt Felelősségú Társaságot. E kft. „az elektromobilitás hazai elterjedését elősegítő közfeladatai körében felelős az országos átjárhatóságot biztosító, elektromos járművek feltöltésére szolgáló töltőinfrastruktúra kiépítéséért”. Az országos átjárhatóság jelentése: ,azon lehetőség megteremtése, amely által kizárólag a nyilvános elektromos töltőpontok igénybevételével Magyarország bármely pontja elérhetôvé válik az elektromos meghajtású gépjármûvek számára". Az eszköztelepítés helyszíneit egy múszaki és társadalmi szempontokat, valamint a már telepített infrastruktúraelemeket is figyelembe vevő modell segítségével választották ki (https://autopro.hu/elemzesek/nagyaranyunovekedes-elott-a-hazai-elektromos-toltohalozat /191035).

Egy harmadik jogszabály-módosítás a 10/2016. (II. 9.) Korm. rendelet Az országos településrendezési és építési követelményekről szóló 253/1997. (XII. 20.) Korm. rendelet, valamint a levegố védelmérôl szóló 306/2010. (XII. 23.) Korm. rendelet módosításáról (Magyar Közlöny (2016/15), 715.) alapvetően a nyilvános töltőberendezéssel már rendelkező településeken bővítette a töltôpontok számát. Lényegében minden nagyobb szuper- és hipermarket ${ }^{6}$ és parkolólétesítmény üzemeltetőjét arra kötelezték, hogy száz parkolóhelyenként bizonyos mennyiségú elektromos töltőállomást kell létesíteniük, új várakozóhelyek megnyitása esetén egyébként arányaiban még többet. Ezek megvalósítására eltérő határidôket szabtak ki az üzlet- és a telepü-

${ }^{6}$ Jogi nyelven ez a napi fogyasztási cikket értékesítő, 300 m²-nél nagyobb bruttó alapterületű üzleteket érinti.

Területi Statisztika, 2020, 60(4): 461-476; DOI: 10.15196/TS600403 
lésnagyság függvényében, de 2020-tól már csak az 1500 m²-nél kisebb és 20 ezer főnél kisebb lélekszámú településen elhelyezkedő egységek kaptak felmentést.

Távolság a legközelebbi nyilvános gyorstöltővel rendelkező településtől, 2019 végén

Distance to the nearest settlement with available public quick charger at the end of 2019

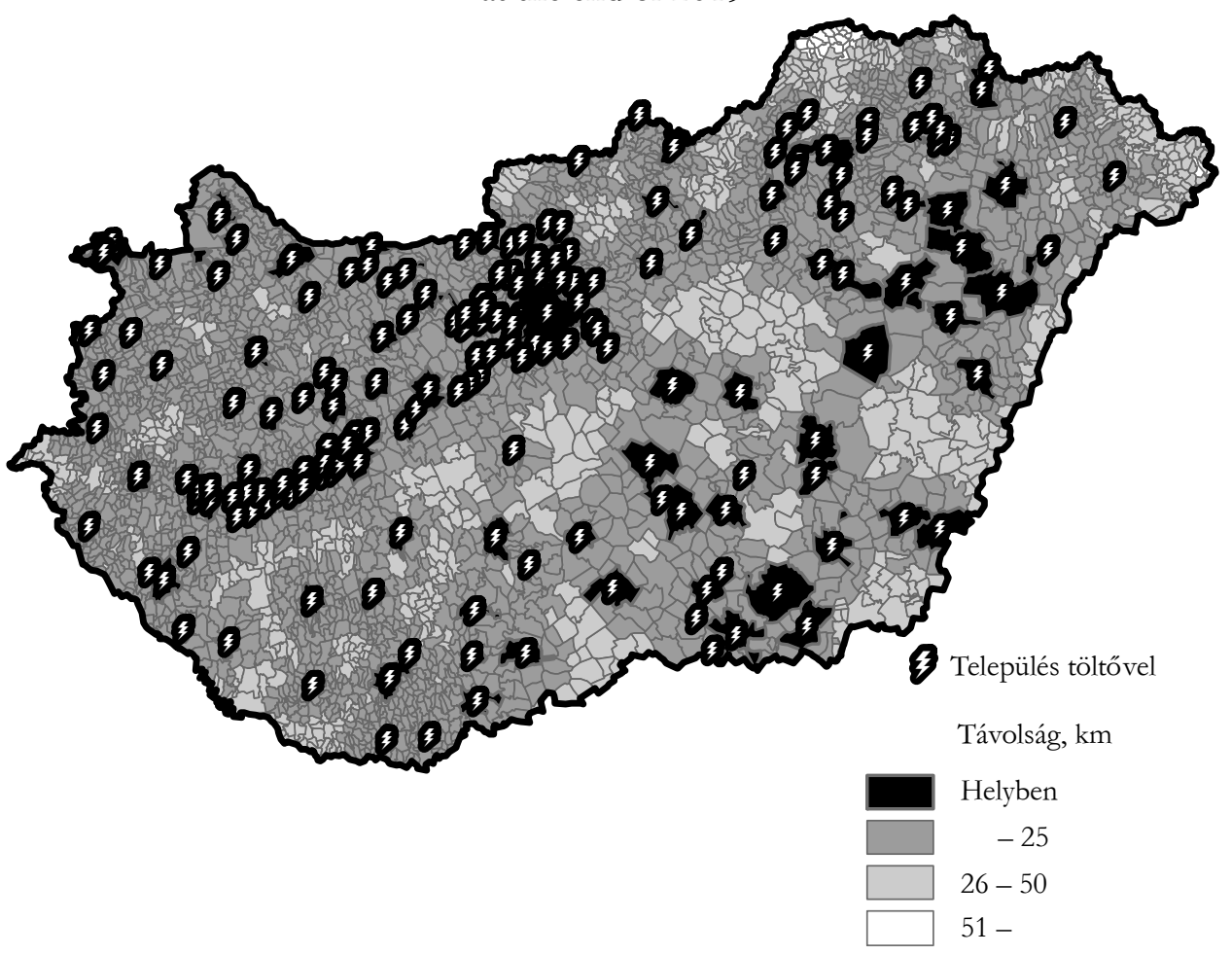

Az e-Mobi és a Jedlik Ányos Terv pályázaton nyertes önkormányzatok töltőtelepítéseivel 2019 végéig országszerte új térségek kapcsolódtak be a hálózatba (5. ábra), és az egyéb beruházók, illetve a törvényben erre kötelezett üzletek által létesített töltőhelyek száma megközelítette az ezret, az egyszerre maximálisan tölthetô autóké a kétezret (2. táblázat). Nyilvános gyorstöltôvel nem ellátott nagyobb térség már nem volt, így ezen a térképen a korábbiakhoz képest más formában jelennek meg a körzetek. A kizárólag autópályáról elérhető töltốpontok helyszínként szerepelnek a térképen, de a körzetek vizsgálatánál nem jelennek meg annál a településnél, amelyikhez közigazgatásilag tartoznak.

Az ország egy-egy északi és északkeleti térségét leszámítva minden településről elérhetô volt 50 kilométeren belül legalább egy nyilvános gyorstöltô - az ismertetett paraméterek szerint, tehát nem feltétlenül közterületen, nem egész napos üzemidő-

Területi Statisztika, 2020, 60(4): 461-476; DOI: 10.15196/TS600403 
vel -, a települések négyötödéről 25 kilométeren belül is. Számos településen több berendezés is múködik, így sok helyütt üzemzavar vagy „teltház” esetén léteznek további lehetőségek.

3. táblázat

\section{Összefoglaló adatok a magyarországi nyilvános gyorstöltőkről}

Summary data regarding public quick chargers in Hungary

\begin{tabular}{c|c|c|c}
\hline \multirow{2}{*}{ Év } & A települések & $\begin{array}{c}\text { A települések népesség- } \\
\text { számmal súlyozott }\end{array}$ & Töltőpontok becsült száma, \\
& \begin{tabular}{c} 
darab \\
\cline { 2 - 3 }
\end{tabular} & $\begin{array}{c}\text { átlagtávolságaa) a legközelebbi töltő́vel rendelkezö telepü- } \\
\text { léstôl (/ csak CHAdeMO), km }\end{array}$ & $<30$ \\
\hline 2013 & 75 & 59 & $<50$ \\
2015 & $66(/ 55)$ & $52(/ 38)$ & $<300$ \\
2017 & $34(/ 33)$ & $22(/ 20)$ & $\sim 2000$ \\
2019 & 18 & 8 &
\end{tabular}

a) A nyilvános gyorstöltôvel rendelkező települések esetében az önmaguktól mért távolság 1 kilométer.

A töltőpontok beruházók szerinti megoszlása, 2019 végén

Distribution of charging points by investors at the end of 2019

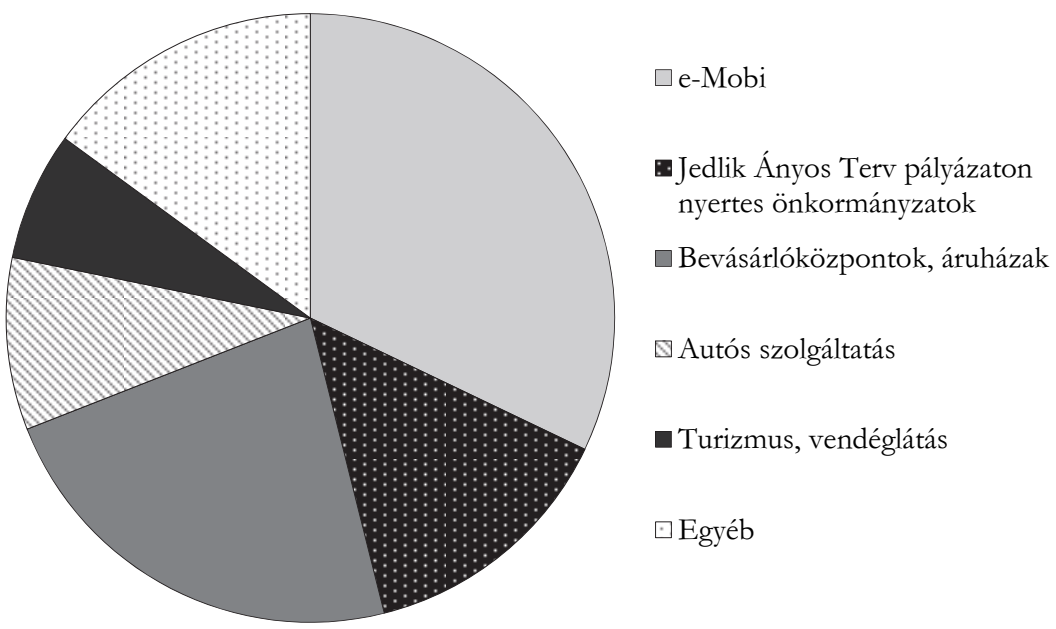

A 2019 végén múködő töltőpontok mintegy harmadába az (azóta a Nemzeti Közművek egyik leányvállalatába integrált) e-Mobi, körülbelül hetedébe a Jedlik Ányos Terv pályázaton nyertes önkormányzatok ruháztak be. A csatlakozók közel negyedét bevásárlóközpontok, áruházak (szuper- és hipermarketek, bútoráruházak, elektronikai szaküzletek stb.) telepítették, majdnem tizedét pedig autós szolgáltatá-

Területi Statisztika, 2020, 60(4): 461-476; DOI: 10.15196/TS600403 
sokhoz köthetô létesítmények (többségében benzinkutak, parkolók, jármúkereskedések). Ennél valamelyest kisebb hányad üzemelt turizmushoz, vendéglátáshoz köthető egységek beruházásaként (szállodáknál, éttermeknél, turisztikai úti céloknál). Az egyéb beruházók közé különböző tevékenységű vállalatok, oktatási intézmények, energiaszolgáltatók tartoznak.

7. ábra

Távolság a legközelebbi nyilvános villámtöltővel rendelkező településtől, 2019 végén

Distance to the nearest settlement with available public rapid charger at the end of 2019

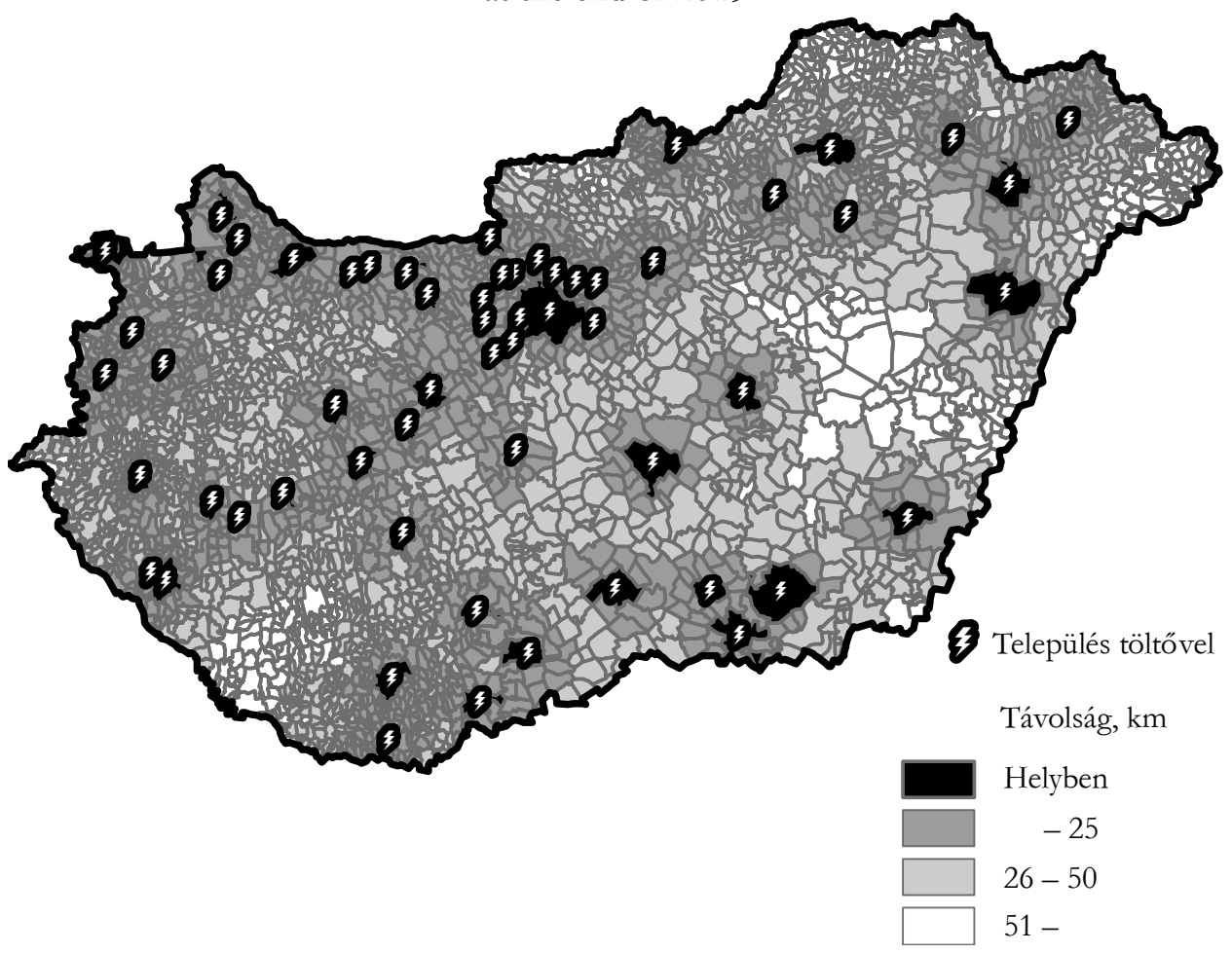

2019 végén a töltési lehetőséggel rendelkező települések mintegy harmadán volt elérhető (legalább $43 \mathrm{~kW}$ teljesítményú) villámtöltô, ami az úton lévőket legjobban segíti az igazán gyors töltési sebességgel. Ezek jellemzően nagyobb városokban, illetve az M1, M7 autópályák mentén helyezkedtek el. Csiszár és szerzőtársai (2017) szerint átlagosan 50 kilométerenként érdemes kijelölni a villámtöltők helyszínét. A hálózatban még akadnak jelentôsebb lefedetlen területek, főleg a hátrányosabb helyzetű (északkeleti, délnyugati, alföldi) országrészeken; a Zalaegerszeg-SiófokPécs, a Szolnok-Debrecen-Békéscsaba vagy a Sárvár-Győr-Veszprém háromszögön belül például egyetlen ilyen berendezés sem található. A töltőpontok vonatkozá- 
sában fontos megemlíteni, hogy a CHAdeMO és CCS2 csatlakozós villámtöltők többségén egyszerre csak az egyik kimenet használható, így két autó egyidejű töltésére nincs lehetőség.

\section{Összefoglalás}

A 2010-es évek első felében főleg Budapesten és a Dunántúlon, autópályák és a Balaton mentén voltak elérhetôk nyilvános gyorstöltők az elektromos autók számára, a hálózat több nagyobb városra sem terjedt ki. Az ország átjárhatósága így nem volt biztosított az ilyen jármúvek tulajdonosainak, számos térségbe nem juthattak el biztonsággal, útközbeni töltési lehetőség hiányában.

Az évtized második felében, különösen az utolsó két év töltőtelepítései javítottak a lefedettségen, 2019 végén az ország szinte összes településéről elérhetôvé vált legalább egy berendezés 50 kilométeren belül, sokukról már 25 kilométeren belül is. Míg a területi lefedettségen nagymértékben lendítettek az állami kezdeményezésû töltőtelepítések, addig a nagyobb településeken a versenyszféra is növelte a töltốpontok számát. A nagyobb teljesítményú és gyorsabb töltést biztosító villámtöltők lefedettsége ugyanakkor még alacsonyabb szintű.

\section{IRODALOM}

BARANYAI, N.-VArjú, V. (2017): A klímaváltozással kapcsolatos attitűdök területi sajátosságai Terïleti Statisztika 57 (2): 160-182. https://doi.org/10.15196/TS570203

CsISzÁR, Cs.-CsONKA, B.-FÖLDES, D. (2017): Elektromosautó töltőhálózat Magyarországon: Hol, mivel és hogyan töltsünk? Városi kö̈llekedés 53 (2): 31-36.

ITM (Innovációs és Technológiai Minisztérium) (2019): Hazai Elektromobilitási Stratégia, Jedlik Anyos Terv 2.0 https://www.kormany.hu/download/f/a9/a1000/Hazai\%20elektromobilit\%C3 \%A1 si \%20strat\%C3\%A9gia.pdf (letöltve: 2020. február)

KISS, J. P.-SzALKAI, G. (2018): Az ingázás mobilitási jellemzői a legutóbbi népszámlálások adatai alapján Terïleti Statisżtika 58 (2): 177-199. https://doi.org/10.15196/TS580203

Orbulov, V.-LÓGÓ, E. (2020): Assessment of Applicability of the Service Design Method on Electric Vehicles Periodica Polytechnica Transportation Engineering 48 (1): 52-56. https://doi.org/10.3311/PPtr.14347.

SPÖtTLe, M.-Jörling, K.-SChimmel, M.-StaAts, M.-Grizzel, L.-Jerram, L.-Drier, W.-GARTNER, J. (2018): Research for TRAN Committee - Charging infrastructure for electric road vehicles European Parliament, Policy Department for Structural and Cohesion Policies, Brussels

TAGAI, G.-BERNARD, J.-ŠIMON, M.-KoÓs, B. (2018): Two faces of peripherality: labour markets, poverty, and population dynamics in Hungary and Czechia Regional Statistics 8 (2): 19-45. https://doi.org/10.15196/RS080204

Területi Statisztika, 2020, 60(4): 461-476; DOI: 10.15196/TS600403 
Vokony, I.-Hartmann, B.-Kiss, J.-SőrÉs, P.-Farkas, C. (2020): Business Models to Exploit Possibilities of E-mobility: An Electricity Distribution System Operator Perspective Periodica Polytechnica Transportation Engineering 48 (1): 1-10. https://doi.org/10.3311/PPtr.13471

Magyar Közlöny (2015/106), 17986.

Magyar Közlöny (2016/15), 715.

Magyar Közlöny (2017/225), 35833.

\section{HONLAPOK}

https://autopro.hu/elemzesek/ nagyaranyu-novekedes-elott-a-hazai-elektromos-toltohalozat /191035

https://e-mobi.hu/en/node/324

https://gyorstoltok.hu/elektromos-autok-es-toltocsatlakozoik

https://www.mobiliti.hu/emobilitas/elektromos-autok-toltese/csatlakozok-fajtai

https://mobiliti.hu/emobilitas/gyakran-ismetelt-kerdesek

https://www.nemzetikozmuvek.hu/Hirek/2018/2018-07-12

https://openchargemap.org/

https://www.plugshare.com/

https://villanyautosok.hu/

https://villanyautosok.hu/2019/10/23/toltotelepites-szabalyai-magyarorszagon-100-milliosbirsag-a-tet 